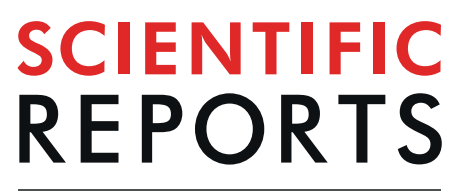

\title{
Blockade of multiple monoamines receptors reduce insulin secretion from pancreatic $\beta$-cells
}

\author{
Mao Nagata ${ }^{1}$, Tomoharu Yokooji ${ }^{1,2}$, Tomoe Nakai ${ }^{1}$, Yumika Miura ${ }^{1}$, Takashi Tomita ${ }^{1}$, \\ Takanori Taogoshi ${ }^{1}$, Yumi Sugimoto ${ }^{3}$ \& Hiroaki Matsuo ${ }^{1 *}$
}

Clinical use of olanzapine frequently causes severe hyperglycemia as an adverse effect. In this study, we elucidated mechanisms by which olanzapine reduced insulin secretion using the hamster pancreatic $\beta$-cell line HIT-T15. Reverse transcriptional-PCR analysis revealed expression of dopamine $\left(D_{2}, D_{3}\right.$ and $\left.\mathrm{D}_{4}\right)$, serotonin $\left(5-\mathrm{HT}_{2 \mathrm{~A}}, 5-\mathrm{HT}_{2 \mathrm{~B}}, 5-\mathrm{HT}_{2 \mathrm{C}}\right.$ and 5- $\left.\mathrm{HT}_{6}\right)$, and histamine $\left(\mathrm{H}_{1}\right.$ and $\left.\mathrm{H}_{2}\right)$ receptors in HIT-T15 cells. Olanzapine decreased insulin secretion from HIT-T15 cells at clinically relevant concentrations (64-160 nM). A dopamine $D_{2}$ agonist, $D_{3}$ antagonist, and $D_{4}$ antagonist suppressed insulin secretion, whereas a $D_{2}$ antagonist and $D_{3}$ agonist increased it. $A$ serotonin $5-H T_{2 B}$ agonist slightly increased insulin secretion, while a $5-\mathrm{HT}_{2 \mathrm{C}}$ antagonist slightly decreased it. Other agonists and antagonists for serotonin receptors did not affect insulin secretion. A histamine $\mathrm{H}_{1}$ agonist increased insulin secretion, whereas an $H_{1}$ antagonist and $H_{2}$ agonist suppressed it. Our results suggest that dopamine $\left(D_{2}, D_{3}\right.$ and $\left.D_{4}\right)$, serotonin $\left(5-\mathrm{HT}_{2 \mathrm{~B}}\right.$ and $\left.5-\mathrm{HT}_{2} \mathrm{C}\right)$, and histamine $\left(\mathrm{H}_{1}\right.$ and $\left.\mathrm{H}_{2}\right)$ receptors, which are expressed on pancreatic $\beta$-cells, directly modulate insulin secretion from pancreatic $\beta$-cells. Thus, olanzapine may induce hyperglycemia in clinical settings by suppressing insulin secretion from pancreatic $\beta$-cells through inhibition of dopamine $\mathrm{D}_{3}$, serotonin $5-\mathrm{HT}_{2 \mathrm{~B}}$ and $5-\mathrm{HT}_{2 \mathrm{C}}$, and histamine $\mathrm{H}_{1}$ receptors.

Schizophrenia is a mental disorder that often appears in adolescence or early adulthood. According to an epidemiological study, the lifetime prevalence of schizophrenia is estimated at $0.7 \%$ worldwide ${ }^{1}$. Patients with schizophrenia typically present with various psychiatric symptoms including positive symptoms, negative symptoms, and cognitive symptoms, which result from dysregulated dopaminergic and non-dopaminergic modulation of the mesocorticolimbic system ${ }^{2}$. Positive symptoms such as delusions and hallucinations often develop during the acute phase and improve over time. In contrast, negative symptoms such as abulia, autism, dullness, and avolition, as well as cognitive deficits, generally become worse and chronic.

Pharmacotherapy with antipsychotic agents is a basic treatment for schizophrenia. Antipsychotic agents can be classified into two types: typical and atypical. Atypical antipsychotic agents such as risperidone, olanzapine, and aripiprazole are currently used as first-line agents to treat schizophrenia because they exhibit lower incidence of extrapyramidal symptoms and hyperprolactinemia compared with typical antipsychotic agents. Olanzapine, an atypical antipsychotic agent, exhibits effectiveness on positive symptoms, negative symptoms, and cognitive deficits by inhibiting multiple receptors such as dopamine, serotonin, histamine $\mathrm{H}_{1}, \alpha$-adrenergic, and muscarinic acetylcholine receptors. According to a prescription survey conducted in 2013, olanzapine was the most frequently used among atypical antipsychotic drugs in Japan and Canada ${ }^{3}$. However, use of olanzapine has reportedly caused serious diabetic ketoacidosis and associated deaths as a result of hyperglycemia. In 2002, the Japan Ministry of Health, Labour, and Welfare issued Emergency Safety Information about the risk of serious hyperglycemia associated with olanzapine administration. However, mechanisms underlying olanzapine-induced hyperglycemia remain incompletely understood. Previous reports have suggested that repeated use of olanzapine caused increasing appetite, weight gain, and obesity, resulting in the development of type 2 diabetes ${ }^{4,5}$. However, olanzapine-induced hyperglycemia has been also observed in patients independent of weight gain ${ }^{6}$. Several reports have shown that olanzapine induced hyperglycemia by induction of apoptosis in insulin-secreting pancreatic $\beta$-cells ${ }^{7}$, insulin resistance ${ }^{8}$, increased glucose production in the liver ${ }^{9}$, and/or increased epinephrine

${ }^{1}$ Department of Pharmaceutical Services, Graduate School of Biomedical and Health Sciences, Hiroshima University, Hiroshima, Japan. ${ }^{2}$ Department of Frontier Science for Pharmacotherapy, Graduate School of Biomedical and Health Sciences, Hiroshima University, Hiroshima, Japan. ${ }^{3}$ Department of Pharmacology, Faculty of Pharmaceutical Sciences, Himeji Dokkyo University, Himeji, Japan. *email: hmatsuo@hiroshima-u.ac.jp 


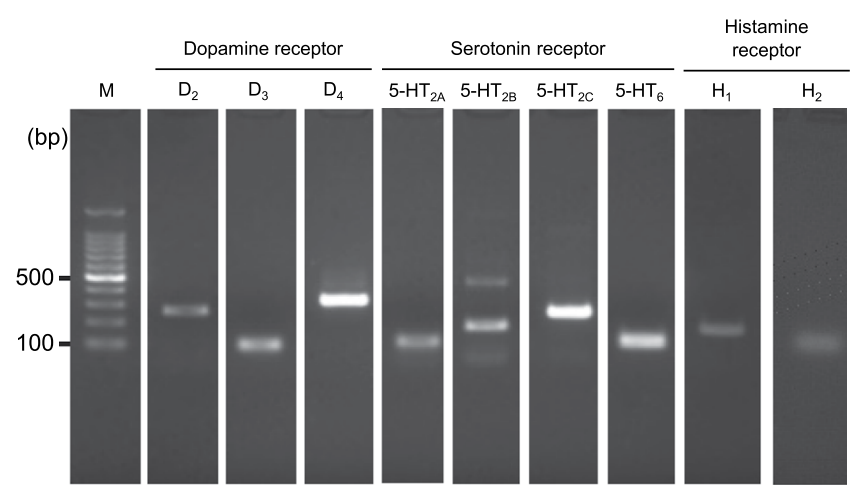

Figure 1. mRNA expression of dopamine $\left(\mathrm{D}_{2}, \mathrm{D}_{3}\right.$, and $\left.\mathrm{D}_{4}\right)$, serotonin $\left(5-\mathrm{HT}_{2 \mathrm{~A}}, 5-\mathrm{HT}_{2 \mathrm{~B}}, 5-\mathrm{HT}_{2 \mathrm{C}}\right.$, and $\left.5-\mathrm{HT}_{6}\right)$, and histamine $\left(\mathrm{H}_{1}\right.$ and $\left.\mathrm{H}_{2}\right)$ receptors in HIT-T15 cells. Total RNA extracted from HIT-T15 cells was reversetranscribed, and first-strand cDNA was synthesized. Target genes were amplified with a set of specific primers (shown in Table 2). For expression analysis of dopamine $\mathrm{D}_{3}$ and $\mathrm{D}_{4}$, all serotonin, and histamine $\mathrm{H}_{2}$ receptors, two-step PCR was performed using nested primers (shown in Table 2). PCR products were separated by electrophoresis using a $2 \%$ agarose gel and stained with ethidium bromide. M, 100-bp ladder size marker.

secretion ${ }^{10}$. We hypothesized that olanzapine can increase hyperglycemia by suppressing insulin secretion from pancreatic $\beta$-cells via blockade of multiple monoamine receptors. In this study, we aimed to elucidate the involvement of dopamine, serotonin, and histamine receptors in insulin secretion from pancreatic $\beta$-cells.

\section{Results \\ Expression of dopamine, serotonin, and histamine receptor mRNA in HIT-T15 cells. Expression of dopamine $\left(\mathrm{D}_{2}, \mathrm{D}_{3}\right.$, and $\left.\mathrm{D}_{4}\right)$, serotonin $\left(5-\mathrm{HT}_{2 \mathrm{~A}}, 5-\mathrm{HT}_{2 \mathrm{~B}}, 5-\mathrm{HT}_{2 \mathrm{C}}\right.$, and $\left.5-\mathrm{HT}_{6}\right)$, and histamine $\left(\mathrm{H}_{1}\right.$ and $\left.\mathrm{H}_{2}\right)$ recep- tors were confirmed by reverse transcriptional (RT)-PCR analysis using specific primers and cDNA from hamster pancreatic cells (HIT-T15). A band corresponding to the expected size of each receptor was observed (Fig. 1).}

Olanzapine decreased insulin secretion from HIT-T15 cells. Olanzapine decreased insulin secretion from HIT-T15 cells to $\sim 80 \%$ of controls at concentrations of $1-1000 \mathrm{nM}$ (Fig. 2). Notably, $\sim 64-160 \mathrm{nM}$ olanzapine has been observed in blood from patients orally administered olanzapine in clinical settings ${ }^{11,12}$.

Effects of dopamine receptor agonists and antagonists on insulin secretion from HIT-T15 cells. The involvement of dopamine receptors in insulin secretion was evaluated using HIT-T15 cells (Fig. 3). Dopamine decreased insulin secretion in a concentration-dependent manner (Fig. 3A), consistent with a previous report ${ }^{13}$. Bromocriptine, a dopamine $\mathrm{D}_{2}$ receptor agonist, decreased insulin secretion in a concentration-dependent manner and this decrease remained constant ( $40 \%$ of control) at dosages over $100 \mathrm{nM}$ (Fig. 3B). In contrast, haloperidol, a dopamine $\mathrm{D}_{2}$ receptor antagonist, increased insulin secretion (Fig. 3C). For the dopamine $\mathrm{D}_{3}$ receptor, the agonist 7-hydorxy PIPAT significantly enhanced insulin secretion (Fig. 3D), whereas the antagonist NGB2904 suppressed it (Fig. 3E). Furthermore, both the dopamine $\mathrm{D}_{4}$ receptor agonist ABT724 and antagonist sonepirazole significantly suppressed insulin secretion to $\sim 80 \%$ of control (Fig. 3F,G). These findings suggest that stimulation of dopamine $\mathrm{D}_{2}$ and $\mathrm{D}_{4}$ receptors decreased insulin secretion from pancreatic $\beta$-cells, whereas stimulation of $\mathrm{D}_{3}$ receptors increased it.

Effects of serotonin receptor agonists and antagonists on insulin secretion from HIT-T15 cells. The involvement of serotonin receptors in insulin secretion was evaluated using HIT-T15 cells (Fig. 4). Insulin secretion was decreased to $\sim 80 \%$ of control by serotonin in a concentration-dependent manner (Fig. $4 \mathrm{~A}$ ). Neither the serotonin $5-\mathrm{HT}_{2 \mathrm{~A}}$ receptor agonist TCB2 nor antagonist MDL11939 had an effect on insulin secretion (Fig. 4B,C). The serotonin 5- $\mathrm{HT}_{2 \mathrm{~B}}$ receptor agonist BW723C86 slightly increased insulin secretion (Fig. 4D), while the antagonist SB204741 exerted no significant effects on secretion (Fig. 4E). Stimulation of serotonin $5-\mathrm{HT}_{2 \mathrm{C}}$ receptors by agonist Ro60-0175 did not affect insulin secretion, although blockade of serotonin $5-\mathrm{HT}_{2 \mathrm{C}}$ receptors by antagonist SB242084 slightly decreased secretion (Fig. 4F). Similar to the serotonin 5- $\mathrm{HT}_{2 \mathrm{~A}}$ receptor, neither the serotonin $5-\mathrm{HT}_{6}$ receptor agonist WAY181187 or antagonist SB399885 had an effect on insulin secretion (Fig. $4 \mathrm{G}, \mathrm{H}$ ). These results suggest that stimulation of serotonin $5-\mathrm{HT}_{2 \mathrm{~B}}$ and $5-\mathrm{HT}_{2 \mathrm{C}}$ receptors can increase insulin secretion from pancreatic $\beta$-cells, although their contributions are much lower than those of dopamine receptors.

Effects of histamine receptor agonists or antagonists on insulin secretion from HIT-T15 cells. We evaluated the involvement of histamine receptors in insulin secretion from HIT-T15 cells (Fig. 5). Histamine decreased insulin secretion at 1-100 nM (Fig. 5A). The histamine $\mathrm{H}_{1}$ receptor agonist 2-pyridylethylamine (2-PEA) increased insulin secretion in a concentration-dependent manner, whereas trans-triprolidine, a histamine $\mathrm{H}_{1}$ receptor antagonist, decreased secretion to $\sim 40 \%$ of control (Fig. 5B,C). In contrast, the histamine $\mathrm{H}_{2}$ receptor agonist amthamine decreased insulin secretion to $\sim 75 \%$ of control in a concentration-dependent manner. In addition, the histamine $\mathrm{H}_{2}$ receptor antagonist tiotidine slightly decreased 


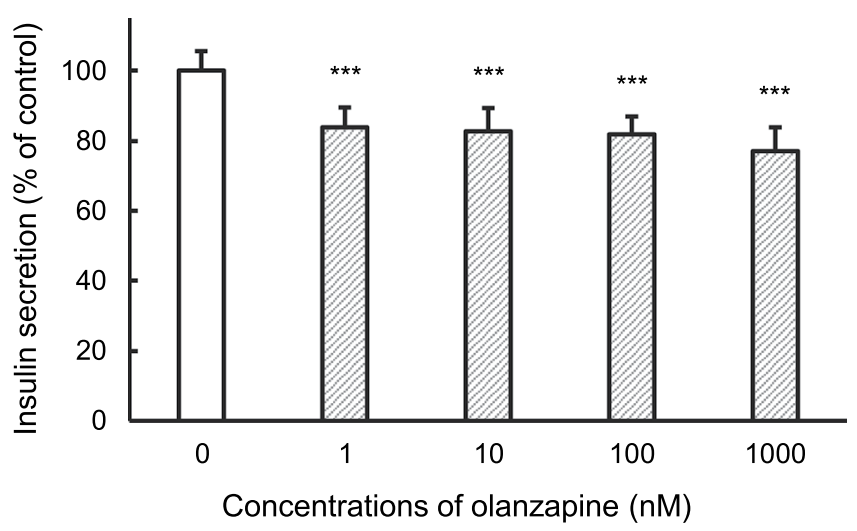

Figure 2. Effect of olanzapine on insulin secretion from HIT-T15 cells. HIT-T15 cells were incubated with medium containing $1 \%$ dimethylsulfoxide (control) or olanzapine for $1 \mathrm{~h}$ at $37^{\circ} \mathrm{C}$. Concentrations of insulin released into the medium were determined using a rat Insulin ELISA kit. Amounts of insulin secretion were normalized to the total protein content of each well. Each value represents mean $\pm S D$ of eight trials. $* * * \mathrm{P}<0.001$ with respect to control.

\begin{tabular}{|l|l|}
\hline Chemical & Cell Viability (\% of control) \\
\hline olanzapine & $101.2 \pm 9.1$ \\
\hline bromocriptine & $108.2 \pm 13.1$ \\
\hline haloperidol & $105.1 \pm 4.7$ \\
\hline 7-hydroxy PIPAT & $94.9 \pm 4.1$ \\
\hline NGB2904 & $106.4 \pm 3.3$ \\
\hline ABT724 & $104.7 \pm 3.3$ \\
\hline sonepiprazole & $99.7 \pm 8.1$ \\
\hline TCB2 & $101.0 \pm 9.1$ \\
\hline MDL11939 & $121.4 \pm 23.9$ \\
\hline BW723C86 & $94.7 \pm 7.9$ \\
\hline SB204741 & $103.2 \pm 10.9$ \\
\hline Ro60-0175 & $103.2 \pm 16.0$ \\
\hline SB242084 & $99.8 \pm 5.0$ \\
\hline WAY181187 & $95.6 \pm 12.5$ \\
\hline SB39985 & $113.4 \pm 8.6$ \\
\hline 2-pyridylethylamine & $105.2 \pm 7.2$ \\
\hline trans-triprolidine & $102.7 \pm 3.4$ \\
\hline amthamine & $89.1 \pm 21.2$ \\
\hline tiotidine & $93.5 \pm 17.2$ \\
\hline
\end{tabular}

Table 1. Effects of chemicals on HIT-T15 cell viability.

insulin secretion (Fig. 5D,E). Thus, stimulation of histamine $\mathrm{H}_{1}$ receptors increased insulin secretion from pancreatic $\beta$-cells, whereas stimulation of $\mathrm{H}_{2}$ receptors decreased secretion.

Olanzapine nor receptor agonists or antagonists affected the viability of HIT-T15 cells. To evaluate whether cytotoxic effects of olanzapine and agonists or antagonists for each receptor occurred, an XTT assay was performed. As shown in Table 1, 1-h exposure of each agent tested did not affect the viability of HIT-T15 cells, indicating that alterations in insulin secretion from HIT-T15 cells induced by these compounds were not the result of cytotoxicity.

\section{Discussion}

Several reports have shown that administration of olanzapine could induce hyperglycemia ${ }^{14,15}$. As olanzapine exerts an antipsychotic effect by inhibiting multiple receptors for dopamine, serotonin, histamine, adrenaline, and acetylcholine, we hypothesized that olanzapine could increase hyperglycemia by suppressing insulin secretion from pancreatic $\beta$-cells through blockade of multiple receptors. In this study, we investigated the involvement of dopamine, serotonin, and histamine receptors in insulin secretion using HIT-T15 cells.

The effects of olanzapine on plasma insulin levels are incompletely understood because doses of olanzapine used in previous animal experiments were higher than used in clinical settings. Nagata et al. ${ }^{10}$ reported that serum concentrations of insulin increased following a single intravenous infusion of olanzapine at a dose of $2.5-10 \mathrm{mg} /$ 

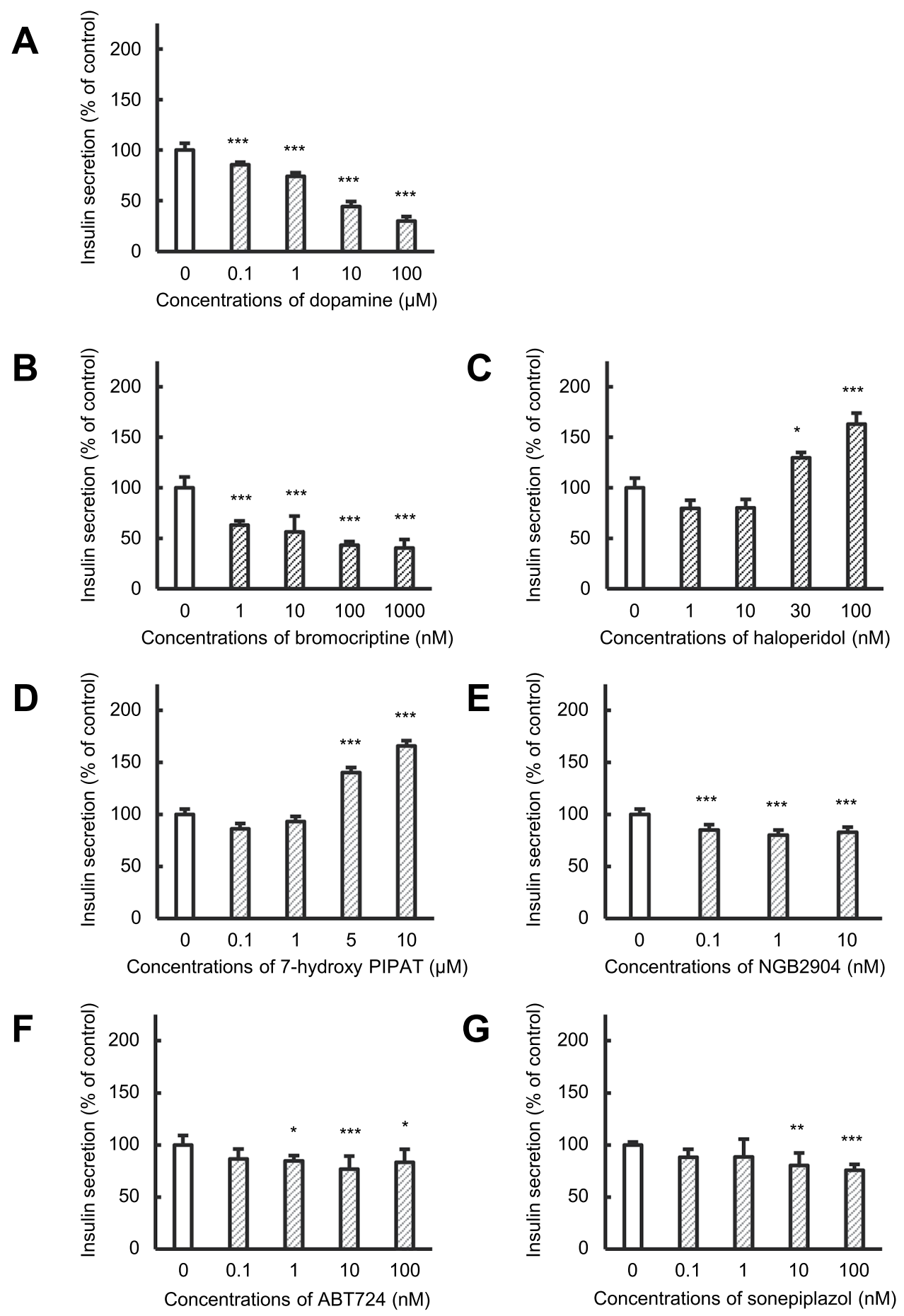

Figure 3. Effects of dopamine receptor agonists and antagonists on insulin secretion from HIT-T15 cells. HIT-T15 cells were incubated with medium containing 1\% dimethylsulfoxide (control), dopamine (A), bromocriptine (B, D 2 agonist), haloperidol (C, D 2 antagonist), 7-hydroxy PIPAT (D, D 3 agonist), NGB2904 (E, $\mathrm{D}_{3}$ antagonist), $\mathrm{ABT} 724\left(\mathbf{F}, \mathrm{D}_{4}\right.$ agonist), or sonepiprazole $\left(\mathbf{G}, \mathrm{D}_{4}\right.$ antagonist) for $1 \mathrm{~h}$ at $37^{\circ} \mathrm{C}$. Concentrations of insulin released into the medium were determined using a rat Insulin ELISA kit. Amounts of insulin secretion were normalized to the total protein content of each well. Each value represents mean $\pm \mathrm{SD}$ of four to eight trials. $* * * \mathrm{P}<0.001$ with respect to control.

$\mathrm{kg}$. In their study, serum concentrations of olanzapine were $394-2763 \mathrm{ng} / \mathrm{mL}(1.26-8.84 \mu \mathrm{M})$ at $15 \mathrm{~min}$ after olanzapine administration. Simpson et al. ${ }^{13}$ reported that olanzapine increased insulin secretion from human islets at concentrations of $1-5 \mu \mathrm{M}$. In clinical settings, olanzapine is administered orally at a dose of 5-20 mg daily, yielding reportedly therapeutic serum concentrations of $20-50 \mathrm{ng} / \mathrm{mL}(64-160 \mathrm{nM})^{12}$. In this study, olanzapine decreased insulin secretion from HIT-T15 cells by $20 \%$ compared with controls at concentrations of 1-1000 nM (Fig. 2). Our preliminary study showed that olanzapine increased insulin secretion from HIT-T15 


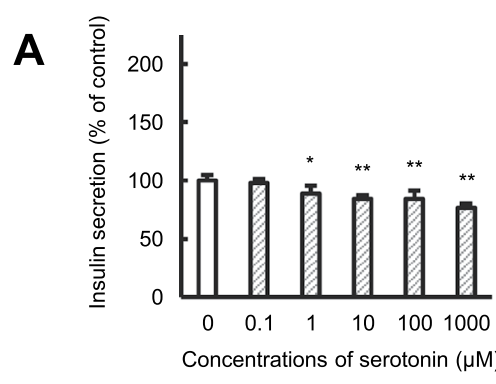

\section{B}
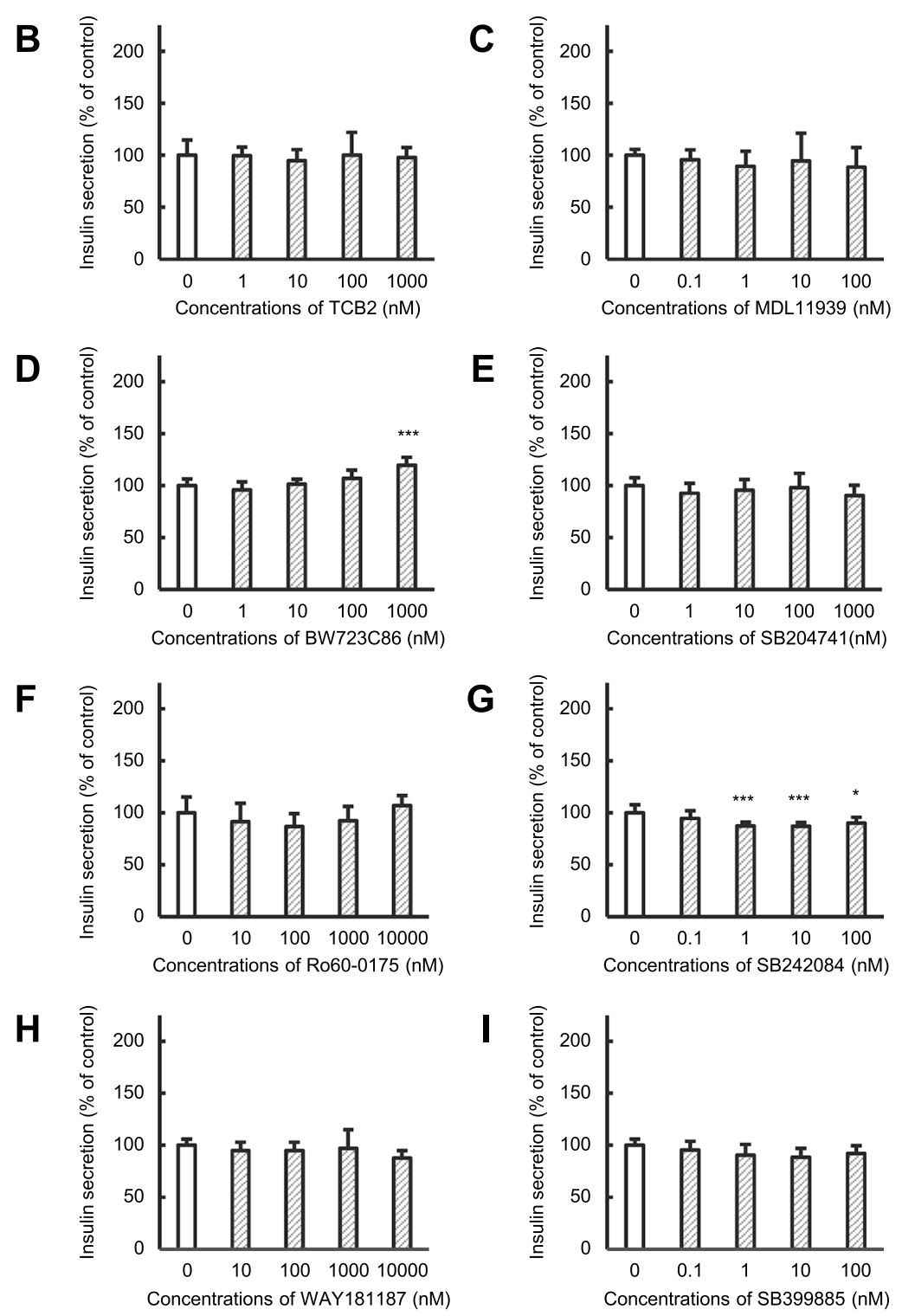

Figure 4. Effects of serotonin receptor agonists and antagonists on insulin secretion from HIT-T15 cells. HIT-T15 cells were incubated with medium containing $1 \%$ dimethylsulfoxide (control), serotonin (A), TCB2 (B, 5- $\mathrm{HT}_{2 \mathrm{~A}}$ agonist), MDL11939 (C, 5- $\mathrm{HT}_{2 \mathrm{~A}}$ antagonist), BW723C86 (D, 5- $\mathrm{HT}_{2 \mathrm{~B}}$ agonist), SB204741 (E, 5- $\mathrm{HT}_{2 \mathrm{~B}}$ antagonist), Ro60-0175 (F, 5-HT $2 \mathrm{C}$ agonist), SB242084 (G, 5-HT $2 \mathrm{C}$ antagonist), WAY181187 (H, 5- $\mathrm{HT}_{6}$ agonist), or SB399885 (I, 5- $\mathrm{HT}_{6}$ antagonist) for $1 \mathrm{~h}$ at $37^{\circ} \mathrm{C}$. Concentrations of insulin released into the medium were determined using a rat Insulin ELISA kit. Amounts of insulin secretion were normalized to the total protein content of each well. Each value represents mean \pm SD of eight trials. $* \mathrm{P}<0.05, * * \mathrm{P}<0.01, * * * \mathrm{P}<0.001$ with respect to control.

cells at concentrations of $10-30 \mu \mathrm{M}$ (data not shown). These findings suggest that olanzapine directly suppresses insulin secretion from pancreatic $\beta$-cells at clinical concentrations. Blood glucose levels were reportedly altered by $20 \%$ when insulin secretion was altered by $25 \%$ after feeding ${ }^{16}$, suggesting that olanzapine can induce hyperglycemia by suppressing insulin secretion from pancreatic $\beta$-cells at clinical concentrations. 

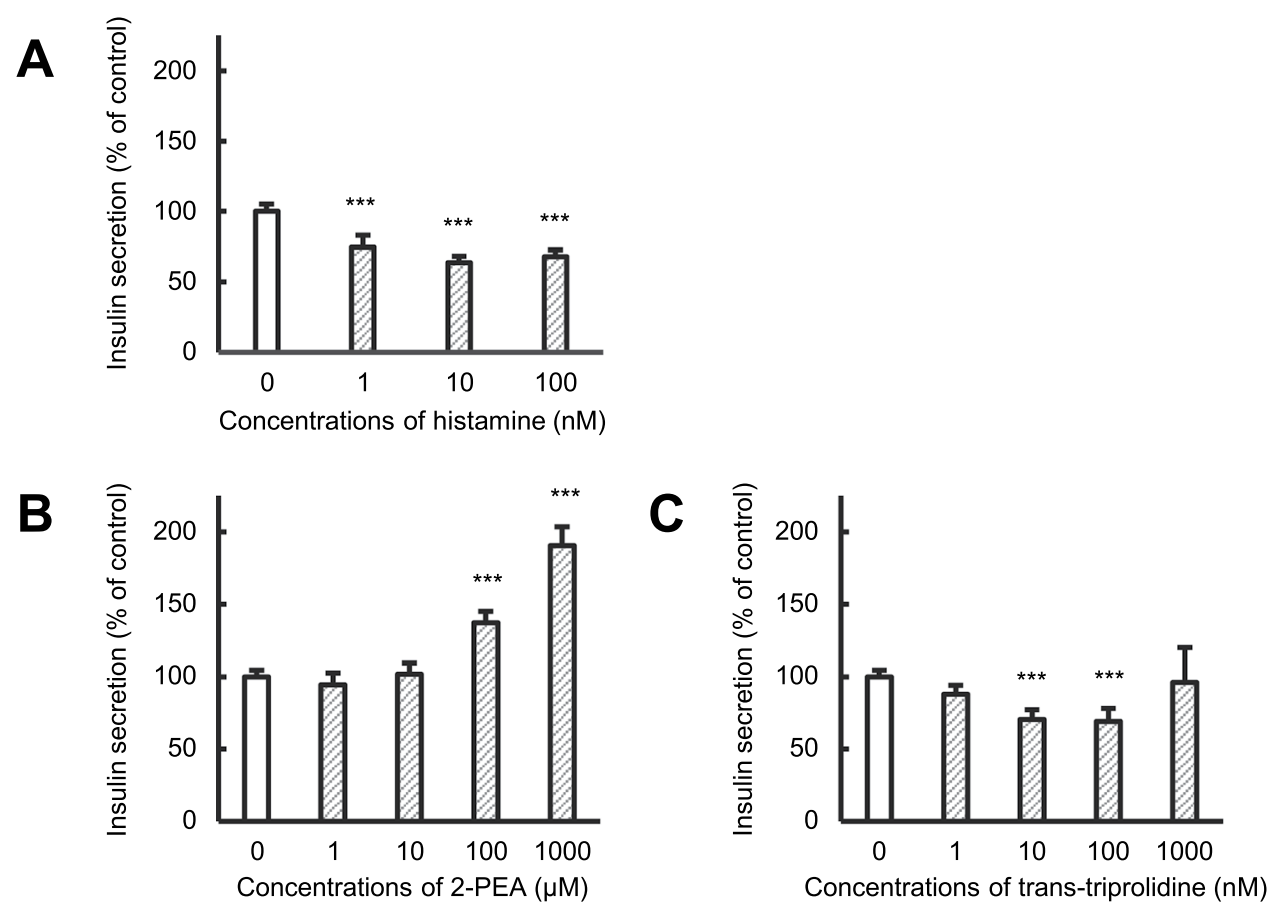

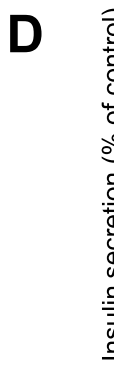
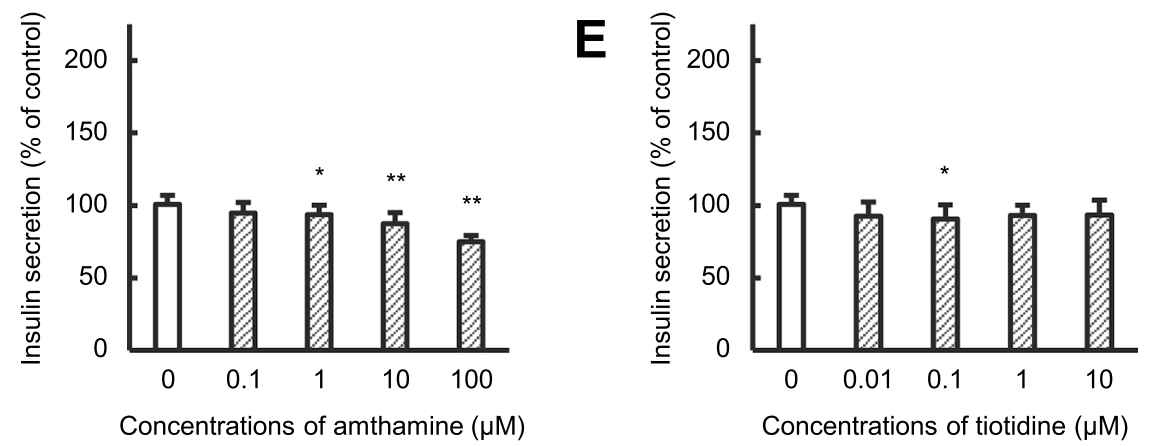

Figure 5. Effects of histamine receptor agonists and antagonists on insulin secretion from HIT-T15 cells. HIT-T15 cells were incubated with medium containing 1\% dimethylsulfoxide (control), histamine (A), 2-pyridylethylamine (2-PEA) (B, $\mathrm{H}_{1}$ agonist), trans-triprolidine $\left(\mathbf{C}, \mathrm{H}_{1}\right.$ antagonist), amthamine $\left(\mathbf{D}, \mathrm{H}_{2}\right.$ agonist $)$, or tiotidine $\left(\mathbf{E}, \mathrm{H}_{2}\right.$ antagonist) for $1 \mathrm{~h}$ at $37^{\circ} \mathrm{C}$. Concentrations of insulin released into the medium were determined using a rat Insulin ELISA kit. Amounts of insulin secretion were normalized to the total protein content of each well. Each value represents mean $\pm S D$ of eight trials. $* * * \mathrm{P}<0.001$ with respect to control.

We demonstrated that dopamine $\mathrm{D}_{2}, \mathrm{D}_{3}$, and $\mathrm{D}_{4}$; serotonin $5-\mathrm{HT}_{2 \mathrm{~A}}, 5-\mathrm{HT}_{2 \mathrm{~B}}, 5-\mathrm{HT}_{2 \mathrm{C}}$, and $5-\mathrm{HT}_{6}$; and histamine $\mathrm{H}_{1}$ and $\mathrm{H}_{2}$ receptors are expressed by HIT-T15 cells (Fig. 1). A few previous studies reported expression of these receptors in human pancreas ${ }^{17-19}$. Rubí et al. ${ }^{17}$ reported the detection of dopamine $\mathrm{D}_{2}$ and $\mathrm{D}_{4}$ receptor mRNAs in human islets. Bonhaus et al. ${ }^{18}$ observed mRNAs for serotonin $5-\mathrm{HT}_{2 \mathrm{~A}}, 5-\mathrm{HT}_{2 \mathrm{~B}}$, and $5-\mathrm{HT}_{2 \mathrm{C}}$ receptors in human pancreas. Although no previous studies reported expression of histamine $\mathrm{H}_{1}$ or $\mathrm{H}_{2}$ receptors in human pancreas, Szukiewicz et al. ${ }^{19}$ reported protein expression of these receptors in pancreatic $\beta$-like cells differentiated from human amniotic epithelial cells by nicotinamide treatment. Thus, the involvement of these receptors in insulin secretion may be observed even in human pancreas.

To evaluate the involvement of dopamine, serotonin, and histamine receptor subtypes in insulin secretion, we examined the effects of agonists and antagonists specific for each receptor subtype on insulin secretion from HIT-T15 cells. With regard to dopamine receptors, stimulation of the dopamine $\mathrm{D}_{2}$ receptor suppressed insulin secretion, whereas its blockade enhanced it (Fig. 3B,C). This result is consistent with a previous report that blockade of dopamine $\mathrm{D}_{2}$ receptor enhanced insulin secretion from human islets ${ }^{13}$. In contrast, stimulation of the dopamine $\mathrm{D}_{3}$ receptor enhanced insulin secretion, whereas its blockade enhanced secretion (Fig. 3D,E). Thus, olanzapine can suppress insulin secretion via blockade of the dopamine $\mathrm{D}_{3}$ receptor. Insulin secretion was increased by either stimulation or blockade of the dopamine $\mathrm{D}_{4}$ receptor (Fig. 3F,G) using specific dopamine $\mathrm{D}_{4}$ agonist ABT724 $\left(\mathrm{EC}_{50}\right.$ value for rat dopamine $\mathrm{D}_{4}$ receptor is $12.4 \mathrm{nM}$ and that for dopamine $\mathrm{D}_{2}$ is $\left.>10 \mu \mathrm{M}\right)$ or antagonist sonepiprazole $\left(K_{i}\right.$ value for human dopamine $D_{4}$ receptor is $10 \mathrm{nM}$ and those for other monoamine receptors are $>2 \mu \mathrm{M}$ ), respectively, which seems contradictory ${ }^{20,21}$. However, these findings can be explained by differences in expression levels between dopamine $\mathrm{D}_{2}$ and $\mathrm{D}_{3}$ receptors. Dopamine can stimulate both dopamine 
$\mathrm{D}_{2}$ and $\mathrm{D}_{3}$ receptors when the dopamine $\mathrm{D}_{4}$ receptor is blocked. Expression levels of dopamine $\mathrm{D}_{2}$ receptor were higher than those of dopamine $\mathrm{D}_{3}$ receptor, as expression of mRNA for dopamine $\mathrm{D}_{3}$ could be detected by two-step PCR with nested primers (Fig. 1). We considered decreased insulin secretion via blockade of the dopamine $\mathrm{D}_{4}$ receptor to arise from stimulation of the dopamine $\mathrm{D}_{2}$ receptor.

For serotonin receptors, stimulation of the $5-\mathrm{HT}_{2 \mathrm{~B}}$ receptor slightly increased insulin secretion from HIT-T15 cells, whereas blockade of the $5-\mathrm{HT}_{2 \mathrm{C}}$ receptor decreased secretion (Fig. $4 \mathrm{C}, \mathrm{F}$ ). In contrast, a 5- $\mathrm{HT}_{2 \mathrm{~B}}$ antagonist, $5-\mathrm{HT}_{2 \mathrm{C}}$ agonist, and both an agonist and antagonist of 5- $\mathrm{HT}_{2 \mathrm{~A}}$ and $5-\mathrm{HT}_{6}$ did not affect insulin secretion. Bennet et al. ${ }^{22}$ demonstrated that stimulation of $5-\mathrm{HT}_{2 \mathrm{~B}}$ receptor increased the glucose-stimulated insulin secretion from mouse and human pancreatic $\beta$-cells by triggering downstream changes in cellular $\mathrm{Ca}^{2+}$ flux that enhance mitochondrial metabolism. These findings suggest that serotonin $5-\mathrm{HT}_{2 \mathrm{~B}}$ and $5-\mathrm{HT}_{2 \mathrm{C}}$ receptors can modulate insulin secretion from $\beta$-cells. Thus, inhibition of serotonin $5-\mathrm{HT}_{2 \mathrm{~B}}$ and $5-\mathrm{HT}_{2 \mathrm{C}}$ receptors may be involved in olanzapine-reduced insulin secretion, although their contributions may be less than those of dopamine receptors. Interestingly, there is one previous reports showing that $5-\mathrm{HT}_{3}$ receptor-mediated insulin secretion was further enhanced in pregnant mice compared to that in normal mice ${ }^{23}$. Thus, it is possible that the contributions of serotonin receptors subtypes to insulin secretion are altered under diseased states.

We also evaluated the involvement of histamine receptors in insulin secretion (Fig. 5). Histamine decreased insulin secretion at $1-100 \mathrm{nM}$ (Fig. 5A). Stimulation of the histamine $\mathrm{H}_{1}$ receptor increased insulin secretion, whereas stimulation of the histamine $\mathrm{H}_{2}$ receptor decreased it (Fig. 5B,D). Thus, insulin secretion from pancreatic $\beta$-cells can be modulated by both histamine receptor subtypes, and olanzapine can suppress insulin secretion via blockade of the histamine $\mathrm{H}_{1}$ receptor.

The roles of endogenous monoamines in the insulin secretion have not been understood completely. Ustione and Piston $^{24}$ reported that dopamine was secreted from pancreatic $\beta$-cells simultaneously with insulin and caused negative feedback inhibition on insulin secretion. In agreement with their report, we also showed that physiological levels of dopamine suppressed the insulin secretion from pancreatic $\beta$-cells (Fig. 3). In contrast, there have been no reports regarding the roles of endogenous serotonin and histamine on insulin secretion. In this study, we used dopamine, serotonin and histamine at concentrations of $0.1-100 \mu \mathrm{M}, 0.1-100 \mu \mathrm{M}$ and $1-100 \mathrm{nM}$, respectively. These concentrations of dopamine and serotonin are higher than those in physiological concentrations which in human plasma are reportedly $\sim 6.5 \mathrm{nM}^{25}$ and $\sim 0.6 \mathrm{pM}^{26}$, respectively. Thus, further studies are necessary to understand the role of endogenous monoamines in the insulin secretion at physiological conditions.

In this study, we did not confirm the expression and involvement of muscarinic acetylcholine receptors on insulin secretion from HIT-T15 cells. Iismaa et al. ${ }^{27}$ reported that muscarinic acetylcholine receptors were expressed on rat pancreatic $\beta$-cells. Furthermore, Henquin et al. ${ }^{28}$ reported that insulin secretion was enhanced via stimulation of muscarinic receptors. Because olanzapine inhibits the muscarinic acetylcholine receptors, it is speculated that olanzapine can suppress the insulin secretion from pancreatic $\beta$-cells via blockade of muscarinic acetylcholine receptors as well as monoamine receptors. Further studies are necessary to clarify the involvement of muscarinic acetylcholine receptors in insulin secretion from pancreatic $\beta$-cells.

In conclusion, we demonstrated that olanzapine suppressed insulin secretion from pancreatic $\beta$-cells via blockade of dopamine $\mathrm{D}_{3}$, serotonin $5-\mathrm{HT}_{2 \mathrm{~B}}$ and $5-\mathrm{HT}_{2 \mathrm{C}}$, and histamine $\mathrm{H}_{1}$ receptors at clinical concentrations in vitro. Although further studies are necessary using human pancreatic $\beta$-cells for in vitro and in vivo animal studies, these findings shed new light on the mechanisms underlying olanzapine-induced hyperglycemia.

\section{Materials and Methods}

Chemicals. Olanzapine and haloperidol were obtained from FUJIFILM Wako Pure Chemical Corporation (Osaka, Japan). Dopamine hydrochloride and bromocriptine were purchased from Sigma-Aldrich (St Louis, MO, USA). 7-Hydroxy PIPAT, ABT724, TCB2, BW723C86, Ro60-0175, WAY181187, 2-PEA, NGB2904, sonepiprazole, MDL11939, SB204741, SB399885, trans-triprolidine, amthamine, and tiotidine were from Tocris Bioscience (Bristol, England, UK). SB242084 was obtained from Toronto Research Chemicals (Ontario, Canada). All other chemicals used were of the highest purity available.

Cell culture. HIT-T15 cells were obtained from Sumitomo Dainippon Pharma (Osaka, Japan). Cells were cultured in Ham's F12K medium (Sigma-Aldrich) containing 10\% fetal bovine serum, 100 units/mL penicillin $\mathrm{G}, 100 \mu \mathrm{g} / \mathrm{mL}$ streptomycin, and $10 \mathrm{mM}$ glucose which corresponds to the physiological blood concentrations in human in an atmosphere of $5 \% \mathrm{CO}_{2} / 95 \%$ air at $37^{\circ} \mathrm{C}$. Cells were subcultured once a week using $0.25 \%$ EDTA and $0.038 \%$ trypsin. Fresh medium was replaced every 2 days. Cells were used between passages 80 and 100 .

RT-PCR analysis. Total RNA was extracted from HIT-T15 cells using an RNeasy Plus Mini Kit (Qiagen, Hilden, Germany) according to the manufacturer's instructions. Next, total RNA was used for reverse transcription to synthesize cDNA using a ReverTra Ace qPCR RT kit (Qiagen). PCR was performed with an iCycler (Bio-Rad Laboratories, Hercules, CA, USA) using KOD-Plus-DNA polymerase (Toyobo, Osaka, Japan). Conditions for PCR were as follows: initial denaturation at $94{ }^{\circ} \mathrm{C}$ for $2 \mathrm{~min}$; denaturation at $94^{\circ} \mathrm{C}$ for $30 \mathrm{sec}$; annealing at optimal temperatures for dopamine, serotonin, and histamine receptors for $30 \mathrm{sec}$; and extension at $68^{\circ} \mathrm{C}$ for $1 \mathrm{~min}$ ( 35 cycles). Primers, annealing temperatures, and product sizes for each receptor are summarized in Table 2. To examine expression of mRNA for dopamine $\mathrm{D}_{3}$ and $\mathrm{D}_{4}$ receptors, and all serotonin receptors, we performed two-step PCR with nested primers due to their lower expression in HIT-T15 cells. Nested primers for each receptor are summarized in Table 2. Conditions for the second round of PCR were the same as those for the first round. PCR products were electrophoresed with a $2 \%$ agarose gel and visualized under ultraviolet light with ethidium bromide. 


\begin{tabular}{|c|c|c|c|}
\hline Gene & Primer sequence & $\begin{array}{l}\text { Annealing } \\
\text { temperature }\left({ }^{\circ} \mathrm{C}\right)\end{array}$ & $\begin{array}{l}\text { Product size } \\
\text { (bp) }\end{array}$ \\
\hline \multirow{2}{*}{ dopamine $\mathrm{D}_{2}$} & forward: 5'-TCGCCATTTGTCTGGGTCCTG-3' & 65 & 261 \\
\hline & reverse: 5'-TGCCCTTTGAGGGGGGTCTTC-3' & & \\
\hline \multirow{2}{*}{$\begin{array}{l}\text { dopamine } \mathrm{D}_{3} \\
\left(1^{\mathrm{st}} \mathrm{PCR}\right)\end{array}$} & forward: 5'-GTCTGGAATTTCAGCCGCATTTGCTGTGA -3' & 62 & 119 \\
\hline & reverse: 5'-ATGACCACTGCTGTGTACCTGTCTATGCTG-3' & & \\
\hline \multirow{2}{*}{ ( $\left.2^{\text {nd }} P C R\right)$} & forward: 5'-CAGCCGCATTTGCTGTGATG-3' & 62 & 94 \\
\hline & reverse: 5'-GTACCTGTCTATGCTGATGGCA-3' & & \\
\hline \multirow{2}{*}{$\begin{array}{l}\text { dopamine } \mathrm{D}_{4} \\
\left(1^{\mathrm{st}} \mathrm{PCR}\right)\end{array}$} & forward: 5'-GTCCGCTCATGCTACTGCT-3' & 60 & 344 \\
\hline & reverse: 5'-GACTCTCATTGCCTTGCGCTC-3' & & \\
\hline \multirow{2}{*}{ ( $\left.2^{\text {nd }} P C R\right)$} & forward: 5'-GCTACTGCTTTACTGGGCCAC-3' & 60 & 329 \\
\hline & reverse: 5'-TCATTGCCTTGCGCTCCCTT-3' & & \\
\hline \multirow{2}{*}{$\begin{array}{l}\text { serotonin } \\
5-\mathrm{HT}_{2 \mathrm{~A}}\left(1^{\text {st }}\right. \\
\text { PCR })\end{array}$} & forward: 5'-CTGGTCATCATGGCAGTGTCCCTAGAGAA-3' & 67 & 291 \\
\hline & reverse: 5'-GGTTCTGGAGTTGAAGCGGCTATGGTGGA-3' & & \\
\hline \multirow{2}{*}{$\left(2^{\text {nd }} P C R\right)$} & forward: $5^{\prime}$-TGATGTCACTTGCCATAGCTG-3' & 55 & 105 \\
\hline & reverse: 5'-AGAGCTTGCTGGGCAAAG-3' & & \\
\hline \multirow{2}{*}{$\begin{array}{l}\text { serotonin } \\
5-\mathrm{HT}_{2 \mathrm{~B}}\left(1^{\mathrm{st}}\right. \\
\text { PCR })\end{array}$} & forward: 5'-ATGCCGATTGCCCTCTTGAC-3' & 67 & 185 \\
\hline & reverse: 5'-CGGGAGTTGCACTGATTGG-3' & & \\
\hline \multirow{2}{*}{$\left(2^{\text {nd }} P C R\right)$} & forward: 5'-GCCGATTGCCCTCTTGACA-3' & 62 & 182 \\
\hline & reverse: 5'-GGGAGTTGCACTGATTGGC-3' & & \\
\hline \multirow{2}{*}{$\begin{array}{l}\text { serotonin } \\
5-\mathrm{HT}_{2 \mathrm{C}}\left(1^{\text {st }}\right. \\
\text { PCR })\end{array}$} & forward: 5'-GGGTCCTTCGTGGCATTCTTCATCCCG-3' & 65 & 273 \\
\hline & reverse: 5'-CTTTTCGTTGTTGATAGCTTGCATGGTGCC-3' & & \\
\hline \multirow{2}{*}{ ( $\left.2^{\text {nd }} P C R\right)$} & forward: 5'-GTGGCATTCTTCATCCCGTTG-3' & 62 & 254 \\
\hline & reverse: 5'-TTGATAGCTTGCATGGTGCT-3' & & \\
\hline \multirow{2}{*}{$\begin{array}{l}\text { serotonin } 5-\mathrm{HT}_{6} \\
\left(1^{\text {st }} \mathrm{PCR}\right)\end{array}$} & forward: 5'-ATGCTGAACGCGCTGTATGG-3' & 60 & 140 \\
\hline & reverse: 5'-GAGAGGATGAGCAGGTAGCG-3' & & \\
\hline \multirow{2}{*}{ ( $\left.2^{\text {nd }} P C R\right)$} & forward: 5'-GTATGGGCGCTGGGTGCTA-3' & 60 & 112 \\
\hline & reverse: 5'-GTAGCGGTCCAGGCTGATG-3' & & \\
\hline \multirow{2}{*}{ histamine $\mathrm{H}_{1}$} & forward: 5'-ACTTGAACCGAGAGCGGAAG-3' & 60 & 178 \\
\hline & reverse: 5'-GGGTTCAGCGTGGAGTTGAT-3' & & \\
\hline \multirow{2}{*}{$\begin{array}{l}\text { histamine } \mathrm{H}_{2} \\
\left(1^{\text {st }} \text { PCR }\right)\end{array}$} & forward: 5'-CCAGCTCCTGTGACTCCAGA-3' & 60 & 353 \\
\hline & reverse: 5'-GGGTTTGGGAAGGTCTGATG-3' & & \\
\hline \multirow{2}{*}{$\left(2^{\text {nd }} P C R\right)$} & forward: 5'-GATCCCTTGCACAAACCCAAC-3' & 60 & 97 \\
\hline & reverse: 5'-TCCTGGTCTGTAGTGTGCGT-3' & & \\
\hline
\end{tabular}

Table 2. Primer sequences, annealing temperatures, and product sizes.

\begin{tabular}{|l|l|l|}
\hline Receptor & Agonist & Antagonist \\
\hline dopamine $\mathrm{D}_{2}$ & bromocriptine & haloperidol \\
\hline dopamine $\mathrm{D}_{3}$ & 7-hydroxy PIPAT & NGB2904 \\
\hline dopamine $\mathrm{D}_{4}$ & ABT724 & sonepiprazole \\
\hline serotonin $5-\mathrm{HT}_{2 \mathrm{~A}}$ & TCB2 & MDL11939 \\
\hline serotonin 5- $\mathrm{HT}_{2 \mathrm{~B}}$ & BW723C86 & SB204741 \\
\hline serotonin $5-\mathrm{HT}_{2 \mathrm{C}}$ & Ro60-0175 & SB242084 \\
\hline serotonin $5-\mathrm{HT}_{6}$ & WAY181187 & SB399885 \\
\hline histamine $\mathrm{H}_{1}$ & 2-pyridylethylamine & trans-triprolidine \\
\hline histamine $\mathrm{H}_{2}$ & amthamine & tiotidine \\
\hline
\end{tabular}

Table 3. Agonists and antagonists specific for dopamine, serotonin, or histamine receptors used in this study.

Insulin secretion assay. Insulin secretion assays were performed according to previous reports ${ }^{29,30}$. Briefly, HIT-T15 cells were seeded at a density of $1.0 \times 10^{5}$ cells/well in 24 -well plates and cultured for $72 \mathrm{~h}$ after seeding. Next, cells were pre-incubated with fresh medium containing $1 \%$ dimethylsulfoxide (DMSO) for $30 \mathrm{~min}$ at $37^{\circ} \mathrm{C}$. After pre-incubation, cells were incubated with fresh medium for $1 \mathrm{~h}$ at $37^{\circ} \mathrm{C}$. To examine the effects of olanzapine or agonists/antagonists for each receptor on insulin secretion, each compound was added to the medium at various concentrations during incubation. Compounds tested are shown in Table 3. After incubation, the concentration of insulin released into the medium was determined using a rat Insulin ELISA kit (Morinaga Institute of Biological Science, Yokohama, Japan) according to our previously reported method ${ }^{31,32}$. Next, residual cells were 
washed with phosphate-buffered saline ( $\mathrm{pH} 7.4$ ), and lysed with $0.3 \mathrm{M} \mathrm{NaOH}$. Concentrations of total protein were determined by Lowry method with bovine serum albumin as the standard. Amounts of insulin secretion were normalized to the total protein content of each well.

XTT assay. HIT-T15 cells were seeded at a density of $1.5 \times 10^{4}$ cells/well in 96-well plates and cultured for $24 \mathrm{~h}$. Next, cells were replaced with serum-free Ham's F12K medium containing optimal concentrations of olanzapine, an agonist or antagonist of each receptor, or $1 \%$ DMSO (control). Cells were incubated for $1 \mathrm{~h}$ at $37^{\circ} \mathrm{C}$. After washing, $200 \mu \mathrm{L}$ of Hank's Balanced Salt Solution containing $225 \mu \mathrm{M}$ XTT and $48 \mu \mathrm{M}$ 1-methoxy-PMS was added to each well. After incubation for $4 \mathrm{~h}$ at $37^{\circ} \mathrm{C}$, absorbance was measured at $450 \mathrm{~nm}$ against $630 \mathrm{~nm}$ as a reference using a Multiskan GO (Thermo Fisher Scientific, Waltham, MA, USA).

Statistical analyses. Data are displayed as mean \pm standard deviation of the mean (SD). Differences in mean values between groups were assessed using Kruskal-Wallis or ANOVA tests, followed by post hoc Tukey test, Dunnett's test, Bonferroni test, or Student's t-test. $\mathrm{P}<0.05$ was considered statistically significant.

Received: 5 July 2019; Accepted: 14 October 2019;

Published online: 11 November 2019

\section{References}

1. McGrath, J., Saha, S., Chant, D. \& Welham, J. Schizophrenia: a concise overview of incidence, prevalence, and mortality. Epidemiol. Rev. 30, 67-76 (2008)

2. Howes, O. D. \& Kapur, S. A neurobiological hypothesis for the classification of schizophrenia: type A (hyperdopaminergic) and type B (normodopaminergic). Br. J. Psychiatry. 205, 1-3 (2014).

3. Pringsheim, T. \& Gardner, D. M. Dispensed prescriptions for quetiapine and other second-generation antipsychotics in Canada from 2005 to 2012: a descriptive study. CMAJ. Open. 2, E225-232 (2014).

4. Hardy, T. A. et al. Impact of olanzapine or risperidone treatment on insulin sensitivity in schizophrenia or schizoaffective disorder. Diabetes, Obes. Metab. 13, 726-735 (2011).

5. Schoemaker, J. et al. Long-Term Efficacy and Safety of Asenapine or Olanzapine in Patients with Schizophrenia or Schizoaffextive Disorder: An Extension Study. Pharmacopsychiatry. 45, E196-203 (2012).

6. Deng, C. et al. Effects of antipsychotic medications on appetite, weight, and insulin resistance. Endocrinol. Metab. Clin. North Am. 42, 545-563 (2013).

7. Ozasa, R. et al. The antipsychotic olanzapine induces apoptosis in insulin-secreting pancreatic $\beta$ cells by blocking PERK-mediated translational attenuation. Cell Struct. Funct. 38, 183-195 (2013).

8. Baptista, T. et al. Comparative effects of the antipsychotics sulpiride or risperidone in rats. I: bodyweight, food intake, body composition, hormones and glucose tolerance. Brain Res. 957, 144-151 (2002).

9. Ikegami, M. et al. Olanzapine increases hepatic glucose production through the activation of hypothalamic adenosine 5'-monophosphate-activated protein kinase. Diabetes Obes. Metab. 15, 1128-1135 (2013).

10. Nagata, M. et al. Mechanism Underlying Induction of Hyperglycemia in Rats by Single Administration of Olanzapine. Biol. Pharm. Bull. 39, 754-761 (2016).

11. Korell, J., Green, B., Rae, A., Remmerie, B. \& Vermeulen, A. Determination of plasma concentration reference ranges for oral aripiprazole, olanzapine, and quetiapine. Eur. J. Clin. Pharmacol. 74, 593-599 (2018).

12. Mauri, M. C. et al. Clinical pharmacology of atypical antipsychotics: an update. EXCLI J. 13, 1163-1191 (2014).

13. Simpson, N. et al. Dopamine-mediated autocrine inhibitory circuit regulating human insulin secretion in vitro. Mol. Endocrinol. 26, 1757-1772 (2012).

14. Castellani, L. N. et al. Glucagon receptor knockout mice are protected against acute olanzapine-induced hyperglycemia. Psychoneuroendocrinology. 82, 38-45 (2017)

15. Ikegami, M. et al. Olanzapine induces glucose intolerance through the activation of AMPK in the mouse hypothalamus. Eur. J. Pharmacol. 718, 376-382 (2013).

16. Tanimoto, M. et al. Comparison of sitagliptin with nateglinide on postprandial glucose and related hormones in drug-naïve Japanese patients with type 2 diabetes mellitus: A pilot study. J. Diabetes Investig. 6, 560-566 (2015).

17. Rubí, B. et al. Dopamine D2-like receptors are expressed in pancreatic beta cells and mediate inhibition of insulin secretion. J. Biol. Chem. 280, 36824-36832 (2005).

18. Bonhaus, D. W. et al. The pharmacology and distribution of human 5-hydroxytryptamine2B (5-HT2B) receptor gene products: comparison with 5-HT2A and 5-HT2C receptors. Br. J. Pharmacol. 115, 622-628 (1995).

19. Szukiewicz, D., Pyzlak, M., Stangret, A., Rongies, W. \& Maslinska, D. Decrease in expression of histamine H2 receptors by human amniotic epithelial cells during differentiation into pancreatic beta-like cells. Inflamm. Res. 59, S205-207 (2010).

20. Brioni, J. D. et al. Activation of dopamine D4 receptors by ABT-724 induces penile erection in rats. Proc. Natl. Acad. Sci. USA 101, 6758-6763 (2004).

21. Merchant, K. M. et al. Pharmacological characterization of U-101387, a dopamine D4 receptor selective antagonist. J. Pharmacol. Exp. Ther. 279, 1392-1403 (1996).

22. Bennet, H. et al. Serotonin (5-HT) receptor $2 \mathrm{~b}$ activation augments glucose-stimulated insulin secretion in human and mouse islets of Langerhans. Diabetologia. 59, 744-754 (2016).

23. Ohara-Imaizumi, M. et al. Serotonin regulates glucose-stimulated insulin secretion from pancreatic $\beta$ cells during pregnancy. Proc. Natl. Acad. Sci. USA 110, 19420-19425 (2013).

24. Ustione, A. \& Piston, D. W. Dopamine synthesis and D3 receptor activation in pancreatic $\beta$-cells regulates insulin secretion and intracellular $[\mathrm{Ca}(2+)]$ oscillations. Mol Endocrinol. 26, 1928-1942 (2012).

25. LeBlanc, J. \& Ducharme, M. B. Plasma dopamine and noradrenaline variations in response to stress. Physiol. Behav. 91, 208-211 (2007).

26. Hervé, P. et al. Increased plasma serotonin in primary pulmonary hypertension. Am. J. Med. 99, 249-254 (1995).

27. Iismaa, T. P. et al. Quantitative and functional characterization of muscarinic receptor subtypes in insulin-secreting cell lines and rat pancreatic islets. Diabetes. 49, 392-398 (2000).

28. Henquin, J. C. \& Nenquin, M. The muscarinic receptor subtype in mouse pancreatic B-cells. FEBS. Lett. 236, 89-92 (1988).

29. Bennet, H. et al. Altered serotonin (5-HT) $1 \mathrm{D}$ and $2 \mathrm{~A}$ receptor expression may contribute to defective insulin and glucagon secretion in human type 2 diabetes. Peptides. 71, 113-120 (2015).

30. Zhang, Q. et al. Serotonin Receptor 2C and Insulin Secretion. PLoS One. 8(1), e54250, https://doi.org/10.1371/journal.pone.0054250 (2013).

31. Tomita, T., Onishi, M., Sato, E., Kimura, Y. \& Kihira, K. Gatifloxacin induces augmented insulin release and intracellular insulin depletion of pancreatic islet cells. Biol. Pharm. Bull. 30, 644-647 (2007).

32. Bito, M. et al. The mechanisms of insulin secretion and calcium signaling in pancreatic $\beta$-cells exposed to fluoroquinolones. Biol. Pharm. Bull. 36, 31-35 (2013). 


\section{Author contributions}

M.N., T.Y., T.T. and H.M. conceived and designed the experiments. M.N., T.N. and Y.M. performed the experiments and analyzed the data. M.N., T.Y., T.T., T.T., Y.S. and H.M. wrote the manuscript. All authors read and approved the final manuscript.

\section{Competing interests}

The authors declare no competing interests.

\section{Additional information}

Correspondence and requests for materials should be addressed to H.M.

Reprints and permissions information is available at www.nature.com/reprints.

Publisher's note Springer Nature remains neutral with regard to jurisdictional claims in published maps and institutional affiliations.

(c) (i) Open Access This article is licensed under a Creative Commons Attribution 4.0 International License, which permits use, sharing, adaptation, distribution and reproduction in any medium or format, as long as you give appropriate credit to the original author(s) and the source, provide a link to the Creative Commons license, and indicate if changes were made. The images or other third party material in this article are included in the article's Creative Commons license, unless indicated otherwise in a credit line to the material. If material is not included in the article's Creative Commons license and your intended use is not permitted by statutory regulation or exceeds the permitted use, you will need to obtain permission directly from the copyright holder. To view a copy of this license, visit http://creativecommons.org/licenses/by/4.0/.

(C) The Author(s) 2019 